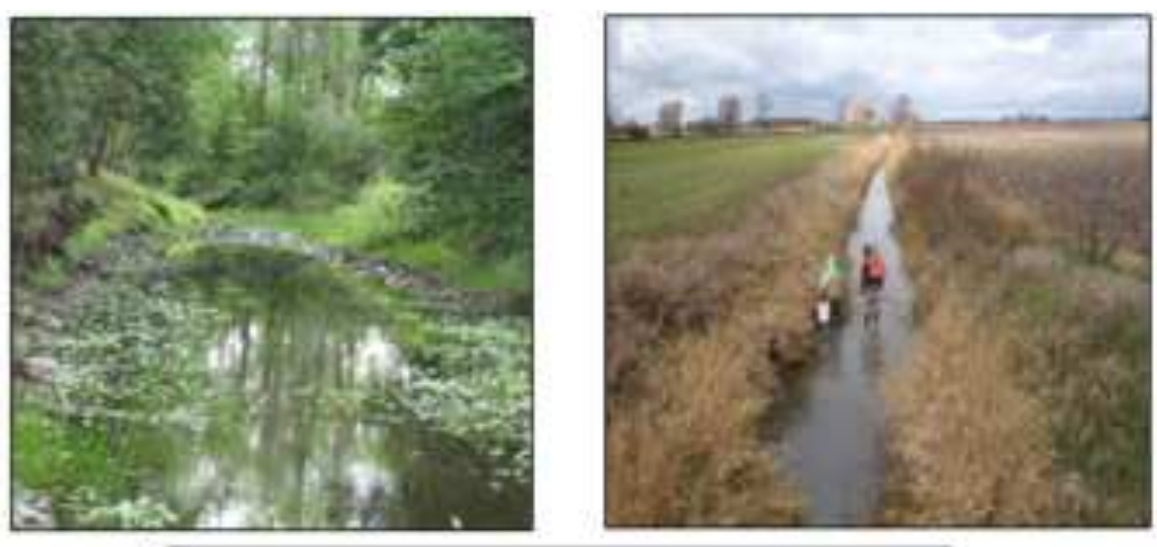

Human Development

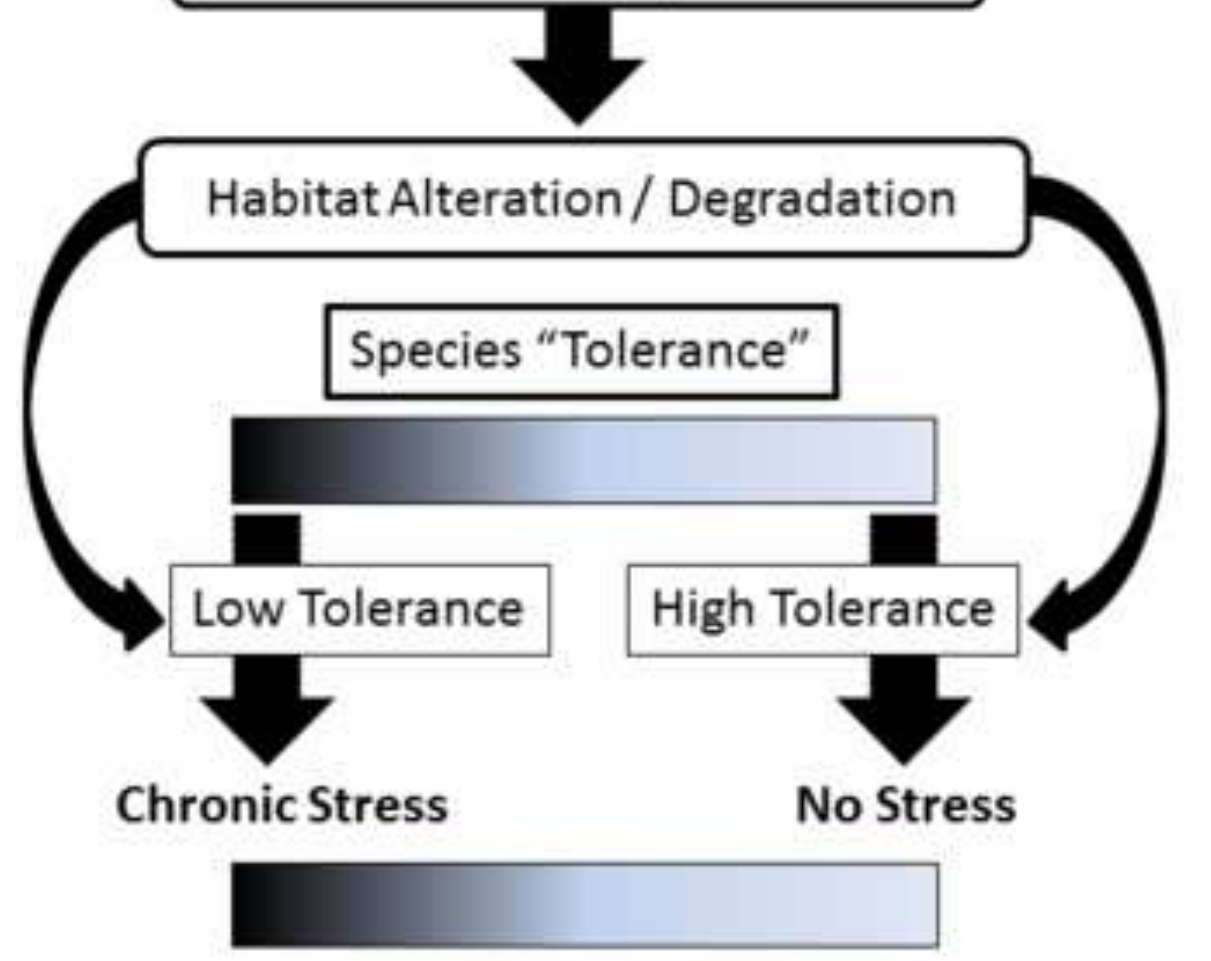

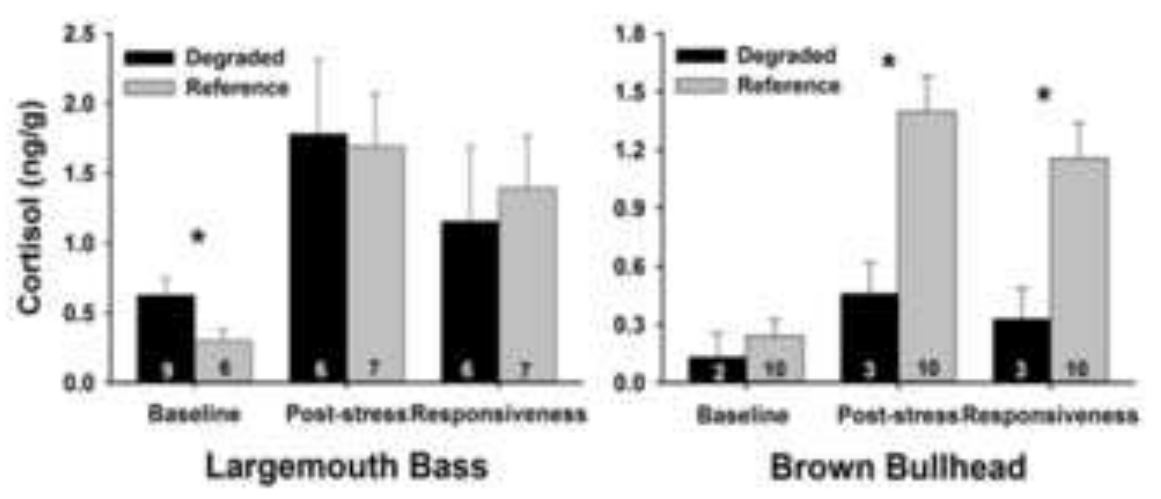
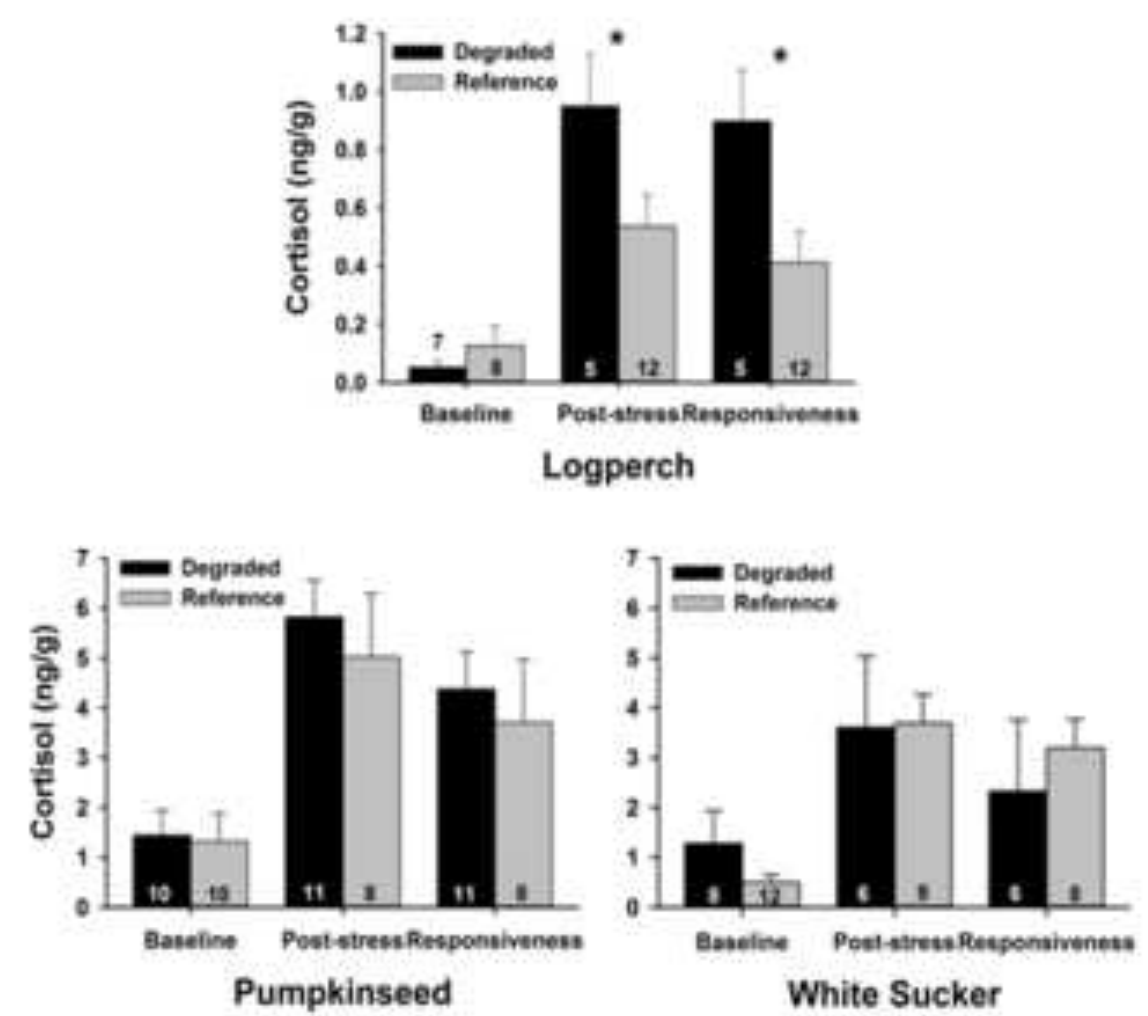


\title{
Stress in the Neighborhood: Tissue Glucocorticoids Relative to Stream Quality for Five Species of Fish
}

\author{
Gregory D. King ${ }^{1}$, Jacqueline M. Chapman ${ }^{2}$, Steven J. Cooke ${ }^{2,3}$, Cory D. Suski ${ }^{1}$ \\ ${ }^{1}$ Department of Natural Resources and Environmental Sciences, University of Illinois at Urbana- \\ Champaign, 1102 S. Goodwin Avenue Urbana, Illinois, USA, 61801 \\ ${ }^{2}$ Fish Ecology and Conservation Physiology Laboratory, Department of Biology, Carleton \\ University, 1125 Colonel By Drive, Ottawa, ON, Canada, K1S 5B6 \\ ${ }^{3}$ Institute of Environmental Science, Carleton University, 1125 Colonel By Drive, Ottawa, \\ Ontario, Canada K1S 5B6 \\ Correspondence: Gregory D. King, Department of Natural Resources and Environmental \\ Sciences, University of Illinois at Urbana-Champaign, 1102 S. Goodwin Avenue Urbana, \\ Illinois, USA 61801 (Phone: 1-217- 244-2237, e-mail: Gdking@ @illinois.edu)
}




\begin{abstract}
Anthropogenic alterations to terrestrial habitat (e.g., urbanization, deforestation, agriculture) can have a variety of negative effects on watercourses that flow through disturbed landscapes. Currently, the relationship between stream habitat quality and fish condition remains poorly understood. The use of physiological metrics such as glucocorticoids (GCs) provides a useful tool for quantifying these effects by relating the health of resident fishes to stream quality. To date, however, most studies that measure GC levels tend to focus on a single, large-bodied species, rather than evaluating how GCs may be influenced differently between species in a community. In this study, we measured cortisol, the glucocorticoid found in fishes, from fish tissues to quantify effects of habitat degradation on the glucocorticoid function of five species of juvenile and small-bodied stream fish which differ ecologically and phylogenetically. Largemouth bass Micropterus salmoides, brown bullhead Ameiurus nebulosus, white sucker Catostomus commersonii, pumpkinseed Lepomis gibbosus, and logperch Percina caprodes were sampled from a reference and a degraded stream. Upon capture, fish were either euthanized immediately, to quantify baseline stress parameters, or following a standardized stressor, to quantify GC responsiveness. As a result of stream degradation largemouth bass possessed altered baseline GC concentrations and brown bullhead and logperch had altered GC responses to a stressor. White sucker and pumpkinseed did not demonstrate any alteration in baseline or post-stress GC concentrations. Together, our results show that different species residing in identical habitats can demonstrate a variety of responses to environmental stress, highlighting the variation in physiological ability to cope under poor environmental conditions, as well as the difficulty of predicting GC dynamics in wild animals. Understanding the relationships between GC function, habitat quality, and population-level processes will increase the ability of
\end{abstract}


researchers and managers to predict how fish communities and aquatic ecosystems will be shaped by anthropogenic environmental change.

Keywords: Conservation physiology, stress, macrophysiology, habitat quality, community, whole-body cortisol 


\section{Introduction}

Natural landscapes have been heavily modified on a global scale, mainly due to human expansion and the requisite resource acquisition, agriculture, and urban development (Foley et al., 2005; Vitousek et al., 1997). These activities have led to the degradation of most ecosystems as natural habitats are lost or fragmented (Fahrig, 1997). Freshwater systems are especially susceptible to human induced habitat destruction (Allan 2004, Olden et al. 2010, Wang et al. 2011), and freshwater fauna are among the most imperiled groups on earth (Ricciardi and Rasmussen, 1999). In their natural state, forests and wetlands contribute to healthy aquatic systems by stabilizing flow, decreasing erosion, and reducing sediment and nutrient inputs (Allan, 2004; Miserendino and Masi, 2010; Richardson, 1994). Human activities, such as urbanization and agriculture, not only remove the benefits provided by these natural habitats, but also alter hydrology, geomorphology, and thermal regimes, while also increasing pollutants, sediment, and nutrient loads (Allan, 2004; Meybeck, 2004; Poff et al., 1997). Combined, these human-induced changes to natural landscapes have resulted in substantial habitat degradation of aquatic ecosystems (Allan, 2004; Dudgeon et al., 2006).

Habitat choice has important physiological consequences for animals (Hendry et al., 2011; Huey, 1991), and reductions in the quality or quantity of suitable habitat can challenge the ability of individuals to persist within a system. For example, agriculture and urbanization are known to alter thermal regimes (Allan, 2004), which can be problematic as fish are ectothermic and thermal refugia are an important resource for maintaining physiological, metabolic, and behavioral optima (Huey, 1991; Magnuson et al., 1979). Land use alterations can also alter water quality, in-stream habitat, and forage quality and availability (Allan, 2004; Miserendino et al., 2011; Theodoropoulos and Iliopoulou-Georgudaki, 2010). The changes to streams resulting 
from human land use activities place animals, especially natives and specialists, in stressful conditions that often push them to their physiological limits (Adams et al. 2002). Over time, these processes can result in changes to populations, communities, and eventually the biodiversity of the system (Adams et al. 2002).

To predict how human disturbance will influence populations, it is important to consider the capacity for adaptation, as well as individual tolerance limits and the potential for acclimatization in novel conditions. A number of techniques are available to answer these questions, including broad-scale examinations, common garden or reciprocal cross experiments, artificial selection, and modeling (Hoffmann and Sgrò, 2011). While these techniques are useful for characterizing the physiological ability of organisms to respond to anthropogenic environmental change, one problem is that many of these studies tend to focus on generalist species and essentially overlook more sensitive species that may be at risk (Blevins et al., 2013; Conover and Schultz, 1995; Falconer, 1990; Nagrodski et al., 2012). This is an important aspect as human land use alterations cause drastic changes in a short time-frame, and specialists may lack the physiological scope to adequately respond, causing population declines (Chevin et al., 2010). To improve our ability to predict the effects of environmental change on biodiversity, it is important that we move beyond a single-species approach and consider the community in studies of organism tolerance.

Using organism-level biological indicators to examine communities, rather than specieslevel, can help us gain a broader understanding of how habitat changes influence ecosystems and biodiversity. The glucocorticoid (GC) stress response is a biological indicator that can be used to assess physiological function (Hontela et al. 1992; Barton et al. 2002), and directly impacts growth, reproduction, and survival (Adams et al. 1989; Adams et al. 2002; Cooke \& Suski 2008). 
The stress response is an adaptive mechanism that increases energy available for activities necessary for short-term survival by stimulating widespread catabolic activities such as proteolysis and gluconeogenesis (Mommsen et al., 1999; Romero, 2004). However, chronic activation of the stress response can become maladaptive by using energetic resources necessary for normal organismal functions, resulting in reduced growth, reproduction, and immune function (Barton, 2002; Mommsen et al., 1999), and can ultimately increase mortality (Selye 1973, Schreck 2000). Chronic stress or pollutants can also result in a muted stress response, resulting in the inability to adequately respond to stressors (Barton, 2002; Romero, 2004). Therefore, altered GC function in substantial portions of populations or communities can be detrimental to their persistence (Dickens and Romero, 2013; Mommsen et al., 1999; Romero and Butler, 2007). In addition, it is important to examine both baseline and post-stress cortisol levels (i.e., scope for stress response) in concert as either one or both, can be affected by disturbances (Blevins et al., 2013; Homan et al., 2003; Hontela et al., 1992; Martínez-Mota et al., 2007), and may also return to normal functioning under chronic stress (Barton, 2002; Schreck, 2000). As such, examining both post-stress and baseline values of cortisol production are critical for detecting individuals or populations experiencing chronic stress (Barton, 2002; Romero, 2004). An examination of GC function of multiple species in stream fish communities can give us a better idea of how human-induced, rapid environmental change is affecting the environment.

The objective of the current study was to quantify the effects of human induced habitat degradation on glucocorticoid levels and the glucocorticoid stress response in a stream fish community. We accomplished this goal by quantifying baseline and post-stress cortisol levels for five sympatric fish species residing in two watersheds that differed in land use characteristics. These species varied in their taxonomic and ecological traits, allowing us to quantify fishes 
differing in trophic guild and evolutionary history are affected by habitat degradation. We chose to examine glucocorticoid function using tissue extracts (Barcellos et al., 2007; Ramsay et al., 2006; Sink et al., 2007), as opposed to plasma. This provided a greater size range of fishes that could be sampled as blood collection from small fishes $(<90 \mathrm{~mm})$ becomes challenging, and many of the fish used in this study were below this range. Together, results from this study will improve our understanding of how communities are shaped by environmental disturbances. 


\section{Materials and Methods}

\subsection{Site selection}

The field-sampling component of this study was performed in tributaries of the St.

Lawrence River, near Cornwall, ON, Canada ( $45^{\circ} 01^{\prime} 16.59^{\prime}$ N, $74^{\circ} 43^{\prime} 49.24$ ” W). To quantify

the impacts of stream quality on glucocorticoids, it was first necessary to define study sites that varied in environmental characteristics. For this land use and a variety of other stream characteristics were examined. Land use data (Table 1), were gathered by the Ontario Ministry of Natural Resources and compiled into the Southern Ontario Land Resource Information System (SOLRIS). Using Quantum GIS Lisboa (1.8.0), the SOLRIS database was integrated with a GIS layer developed by the Raisin Region Conservation Authority that delineated watershed boundaries within the study area. Analyses of land use data identified two streams, Hoople and Gunn Creek, which were ideally suited for this study as they differed greatly in land use characteristics and were in close geographic proximity. Hoople Creek's (45 01' 19.09' N, $\left.74^{\circ} 59^{\prime} 32.37^{\prime \prime} \mathrm{W}\right)$ watershed consisted of about $41 \%$ forests and wetlands, while Gunn Creek's $\left(45^{\circ} 11^{\prime} 30.57^{\prime \prime} \mathrm{N}, 74^{\circ} 22^{\prime} 32.38^{\prime \prime} \mathrm{W}\right)$ watershed had $<10 \%$ of forests or wetlands (Table 1). A large portion of Gunn Creek's watershed consists of agriculture. As a result of land use practices, Gunn Creek had an average total phosphorus (TP) concentration exceeding $100 \mu \mathrm{g} / \mathrm{L}$ during the summer months, while Hoople Creek averaged less than half of that $(39 \mu \mathrm{g} / \mathrm{L})$ (Ontario Ministry of the Environment 2009). Gunn creek also showed signs of fecal contamination and potentially high levels of disease causing organisms in the water, indicated by elevated levels of $E$. coli bacteria loads, reaching twice the level of Hoople Creek $(8.3 \mathrm{CFU} / \mathrm{mL}$ and 3.9 CFU/mL, respectively) (Raisin Region Conservation Authority). The Ontario Ministry of the Environment regularly uses Hoople Creek as a reference stream when assessing stream 
quality because it is considered one of the least impacted streams in this region (Ontario Ministry of the Environment 2009). Seasonal fish community samples were also performed in these streams throughout 2012. These samples showed a higher Sannon-Weiner Diversity in Hoople Creek vs Gunn Creek (2.42 and 1.79, respectively), and found Hoople Creek to have nearly double the effective number of species as Gunn Creek (11.2 and 6.0, respectively; Filgueira et al., 2016). During our sampling trips Hoople Creek possessed higher dissolved oxygen than Gunn Creek (12.98 mg/L and 9.6 mg/L, respectively), and these dissolved oxygen levels should not be problematic for fishes; both streams were similar in average temperature $\left(9.5^{\circ} \mathrm{C}\right.$ in Hoople Creek and $10.0^{\circ} \mathrm{C}$ in Gunn Creek). For these reasons, Hoople Creek was considered to be of high habitat quality and served as a reference stream in this study, while Gunn Creek was considered to be low quality and served as the degraded stream.

\subsection{Field sampling}

Fish sampling for this study was performed over a 2 week period in October 2012, and all procedures were approved by the University of Illinois Institutional Animal Care and Use Committee (Protocol \#12058). Using a backpack electrofisher (Halltech Aquatic Research Inc., HT-2000 Battery Backpack Electrofisher), we collected largemouth bass (Micropterus salmoides) $(\mathrm{n}=15$ from Gunn Creek and 13 from Hoople Creek), white sucker (Catostomus commersonii) ( $\mathrm{n}=14$ from Gunn Creek and 20 from Hoople Creek), brown bullhead (Ameiurus nebulosus) ( $\mathrm{n}=5$ from Gunn Creek and 20 from Hoople Creek), pumpkinseed (Lepomis gibbosus) $(\mathrm{n}=21$ from Gunn Creek and 17 from Hoople Creek) and logperch (Percina caprodes $)(\mathrm{n}=12$ from Gunn Creek and 18 from Hoople Creek). These species were chosen because they were among the few that reside in both streams, are taxonomically diverse, and 
occupy a variety of ecological niches (Table 2). To reach sufficient sample sizes, both streams required 4 sampling trips. We waited at least 24 hours between sampling efforts to allow any potential cortisol elevations in disturbed but uncaptured fish to return to baseline levels (Milligan, 1996; Mommsen et al., 1999; van Raaij et al., 1996).

Once fish of the target species were stunned by the electrofishing gear, they were immediately netted and assigned to either the baseline or stress treatment. The first fish captured from each species (per stream) was randomly assigned a treatment, and subsequent fish were alternately assigned each treatment. Fish in the baseline treatment were euthanized via cerebral percussion within 30 seconds of being stunned by the electrofisher, which should precede any cortisol elevation related to electroshocking, handling, or sampling (Maule and Mesa, 1994; Mesa and Schreck, 1989; Romero and Reed, 2005). Fish assigned to the stress treatment were subjected to a standardized challenge previously shown to induce maximal elevations of circulating cortisol in fish (Cook et al., 2012; O’Connor et al., 2011). For this, each individual was subjected to 3 minutes of air exposure while being held in a moist, padded, and covered container, and then transferred to a $20 \mathrm{~L}$ bucket filled with fresh stream water to allow circulating cortisol levels to rise. Based on previous literature, 25 minutes was chosen as the elevation period for largemouth bass (O’Connor et al., 2011), 40 minutes for pumpkinseed (Cook et al., 2012), and 30 minutes for logperch, white sucker, and brown bullhead (Acerete et al., 2004; Limsuwan et al., 1983). The different elevation periods were chosen to target the period of maximum cortisol elevation. So, while the elevation period differed between species, the constant was that fish were euthanized at the zenith of the circulating cortisol concentration curve. However, the duration of the stress response has not been established for all species used in this study, so for some we used the most closely related species possible. At the conclusion of 
the elevation period, fish were euthanized via cerebral percussion. Once euthanized, all fish were measured (total length), wrapped in aluminum foil, and stored in a dry shipper charged with liquid nitrogen for laboratory processing. A small number of fish ( $\mathrm{n}=9$ of 34 total white sucker, spread with 6 from Gunn and 3 from Hoople and $n=5$ brown bullhead, spread with 4 from Gunn and 1 from Hoople of 25 total) were too large for a whole-body sample to be taken. Therefore, these fish were cut in half and the posterior body section was brought back to the lab for cortisol processing. The size limitation varied between species, but the smallest fish sectioned was a 130 $\mathrm{mm}$ white sucker and the largest was a $240 \mathrm{~mm}$ brown bullhead. Sectioning was not expected to influence cortisol values as cortisol is not stored in any tissue or organs after production. Cortisol circulates throughout the entire body within the blood acting on a number of tissues and organs (Mommsen et al., 1999; Romero and Butler, 2007). That being said, future research is needed to determine if various organs or tissues possess a higher or lower cortisol levels. Sex of the fish used in the study was not determined. In fish, the glucocorticoid stress response usually only differs between sexes immediately before or during the reproductive period (Hanson et al., 2008). As our study was conducted in October, outside the reproductive period, sex was likely not a significant factor. 


\subsection{Laboratory analysis}

Cortisol was extracted from the collected tissues (whole-body except for those fish where only the posterior section was taken) using a modification of the ethyl ether/vegetable oil method outlined and validated by Sink et al. (2007). Briefly, fish were sectioned in to pieces small enough to use with the homogenizer. The tissue was then weighed (g) and homogenized in $3 \mathrm{~mL}$ phosphate buffered saline (PBS), plus an extra $1 \mathrm{~mL}$ for fish over $10 \mathrm{~g}$. After homogenization, $100 \mu \mathrm{L}$ of vegetable oil per gram of fish tissue was added to the sample. The vegetable oil had been previously analyzed to ensure is did not contain cortisol and was added to increase the final extract volume, ensuring each sample could be assayed individually. For fish up to $6.5 \mathrm{~g}, 7 \mathrm{~mL}$ of ethyl ether was then added to the homogenate; for every gram over $6.5 \mathrm{~g}$, samples received 1 $\mathrm{mL}$ extra, up to a maximum of $15 \mathrm{~mL}$. The sample was then centrifuged for 10 minutes at 3000 $\mathrm{rpm}$ and placed in a $-80^{\circ} \mathrm{C}$ freezer for 2 hours. The unfrozen ethyl ether portion was then decanted into a separate test tube and evaporated under a gentle stream of gaseous nitrogen for 2 hours, yielding a lipid extract containing cortisol. This extraction procedure was performed a second time on the thawed homogenate, and the second lipid extract was added to the first. Fish size did vary between species, thus necessitating a change in volumes of extraction reagents (Table 3). While varying volumes may affect extraction efficiency between species, this would not affect our results as we did not quantitatively compare cortisol concentrations between species. The extract was stored at $-20^{\circ} \mathrm{C}$ until a commercially available enzyme linked immunosorbant assay (ELISA) was performed to quantify cortisol concentrations (Enzo Life Sciences, Cortisol EIA Kit [901-071], BioAssay Systems) (Sink et al., 2008, 2007). This assay has a detection limit of $0.0567 \mathrm{ng} \mathrm{mL}^{-1}$, therefore, samples with cortisol concentrations below the detection limit were assigned values equal to the detection limit prior to calculations of cortisol 
per gram of fish weight (Haddy and Pankhurst 1999; Ramsay et al. 2006). Extraction efficiency was assumed to be comparable those of Sink et al. (2007).

Condition of fish was also assessed using Fulton's Condition Factor (K). Condition could only be determined from fish in which a whole-body sample was taken as weight was not measured until fish were brought back to the lab.

\subsection{Statistical analysis}

For analyses, we were interested in three different metrics related to intraspecific stress: baseline cortisol concentration, post-stress cortisol concentration, and glucocorticoid responsiveness (post-stress - baseline). To determine if baseline and post-stress cortisol levels differed between streams, a Welch's t-test was performed separately for each species (Ruxton, 2006). Homogeneity of variances is not an assumption of this test; however, the assumption of normality was assessed using a visual inspection of the fitted residuals on a quantile-quantile plot (Anscombe and Tukey, 1963). If this assumption was not met, data were rank transformed prior to performing a Welsh's t test (Zimmerman and Zumbo, 1993). To approximate GC responsiveness values within a species, we subtracted mean baseline cortisol concentrations for a stream from the post-stress levels of individual fish sampled from the same stream. While this does not account for variation in baseline concentrations within a stream, it is important to minimize the effect that differences in baseline concentrations between streams will have on the results (i.e. differences in baseline concentrations may cause responsiveness values to appear the same when they aren't). Because both comparing maximal cortisol values and comparing responsiveness with averaged (as opposed to individually measured) baseline cortisol levels are imperfect, both were analyzed to ensure consensus of the results. Responsiveness values were then compared using a Welch's t-test on ranked or raw data, dependent on normality of the data. 
All statistical analyses were performed using JMP 10.0 (SAS Institute, Cary, NC, USA).

Rejection of the null hypothesis $(\alpha)$ for all tests was $\mathrm{P} \leq 0.05$, and all values are reported as means \pm standard error $(\mathrm{SE})$ where appropriate.

The equation for Fulton's Condition factor $(\mathrm{K})$ is

$$
K=\left(\frac{W}{L^{3}}\right) \times 100,000
$$

And, once $\mathrm{K}$ was determined, the condition of fish between streams was examined using Welch's t-test. Again the assumption of normality was checked using a visual inspection of the fitted residuals on a quantile-quantile plot (Anscombe and Tukey, 1963).. Logperch data did not meet this assumption and were unable to be normalized, so a non-parametric Wilcoxon RankSum test was performed for this species. Furthermore, condition could not be assessed for brown bullhead as only one fish from Gunn Creek had an accurate weight (the rest were sectioned in the field). 


\section{Results}

Baseline cortisol levels were unaffected by habitat quality for all species examined except largemouth bass (Figure 1a), where a higher baseline cortisol concentration was present in the degraded stream (Gunn Creek) relative to the reference stream $\left(\right.$ Hoople Creek) $\left(\mathrm{t}_{(12.5)}=-2.24, \mathrm{P}=\right.$ 0.022). There were no differences in baseline cortisol concentrations for brown bullhead $\left(\mathrm{t}_{(1.5)}=\right.$ $0.43, \mathrm{P}=0.72)$, logperch $\left(\mathrm{t}_{(12.04)}=0.79, \mathrm{P}=0.44\right)$, pumpkinseed $\left(\mathrm{t}_{(16.89)}=-0.52, \mathrm{P}=0.61\right)$, or white sucker $\left(\mathrm{t}_{(15.1)}=-0.30, \mathrm{P}=0.78\right)$ across the two streams examined (Figure $\left.1 \mathrm{~b}-\mathrm{e}\right)$.

Following the stressor treatment, both brown bullhead and logperch demonstrated a difference in post-stress cortisol between streams (Figure 1b, c). More specifically, post-stress cortisol concentrations in brown bullhead were 3-times greater in the reference stream than in the degraded stream $\left(\mathrm{t}_{(7.7)}=3.86, \mathrm{P}=0.0026\right)$. In contrast, logperch had higher post-stress cortisol concentrations in the degraded stream than in the reference stream, with the mean value from the degraded stream being nearly double that of logperch from the reference stream $\left(\mathrm{t}_{(8.2)}=-1.96, \mathrm{P}\right.$ $=0.042)$. There was no difference in post-stress cortisol concentrations for largemouth bass $\left(\mathrm{t}_{(10.6)}=1.03, \mathrm{P}=0.33\right)$, pumpkinseed $\left(\mathrm{t}_{(9.32)}=-0.30, \mathrm{P}=0.77\right)$ or white sucker $\left(\mathrm{t}_{(6.6)}=0.058, \mathrm{P}\right.$ $=0.96)$ between streams (Figure 1a, d, e).

Responsiveness values, defined as post-stress cortisol concentration minus baseline, were then examined. Both brown bullhead and logperch demonstrated a difference in post-stress cortisol between streams (Figure 1b, c). More specifically, responsiveness values in brown bullhead were greater in the reference stream than in the degraded stream $\left(\mathrm{t}_{(7.7)}=3.41, \mathrm{P}=\right.$ 0.0048). In contrast, logperch had higher responsiveness values in the degraded stream than in the reference stream $\left(\mathrm{t}_{(8.2)}=-2.93, \mathrm{P}=0.0091\right)$. There was no difference in responsiveness 
values for largemouth bass $\left(\mathrm{t}_{(10.6)}=1.5, \mathrm{P}=0.15\right)$, pumpkinseed $\left(\mathrm{t}_{(9.32)}=-0.26, \mathrm{P}=0.8\right)$ or white sucker $\left(\mathrm{t}_{(6.6)}=0.056, \mathrm{P}=0.59\right)$ between streams (Figure 1a, $\mathrm{d}, \mathrm{e}$ ).

Fish condition between the degraded and reference stream was compared for 4 of the 5 species used in this study. Condition between streams was only found to differ for largemouth bass, having higher condition in the degraded stream (Table 4). 


\section{Discussion}

Stream quality significantly influenced the release of glucocorticoids for three of the five fish species examined. Relative to the reference stream, largemouth bass demonstrated elevated baseline levels in the degraded stream, brown bullhead showed an impaired ability to mount a stress response, and logperch exhibited a greater stress response. Cortisol is released under stressful conditions including acute stressors such as failed predation events (Romero, 2004) and fisheries interactions (i.e., capture and release; Suski et al. 2003) or chronic stressors such as habitat fragmentation (Martínez-Mota et al., 2007) and water quality degradation (Hontela et al., 1992). This is an adaptive response that alters a suite of organismal processes (e.g., behavior, energy allocation) and increases the likelihood of short-term survival (Barton, 2002; Romero, 2004). Elevated baseline cortisol levels, observed in largemouth bass, likely resulted from chronic activation of the stress axis. This has been shown to occur when animals inhabit suboptimal habitats, such as those with extreme temperatures, pollution, or insufficient food resources (Dallman and Bhatnagar, 2001; Romero, 2004). However, largemouth bass residing in the degraded stream possessed higher body condition despite elevated baseline cortisol levels. The cause of this is unclear, but it may mean lack of forage is not an issue in this stream, but other problems related to agricultural development, such as pollution, sedimentation, or habitat degradation or loss (Allan, 2004; Laub and Palmer, 2009). If an animal is unable to acclimatize to these sub-optimal conditions, chronic cortisol release can lead to impaired immune function and the exhaustion of energy stores, which are necessary for growth and reproduction (Mommsen et al., 1999; Romero, 2004).

In contrast, the other two species, brown bullhead and yellow perch, demonstrated unchanged baseline cortisol concentrations, but altered stress responses. This can occur for a 
variety of reasons, such as acclimation, which is why it is often necessary to assess baseline cortisol levels as well as the magnitude of the stress response to determine the health of an animal. In this study, brown bullhead residing in the degraded stream demonstrated a reduced maximal stress response relative to individuals from the reference stream. Fewer brown bullhead were captured from the degraded stream due to low densities, and we were unable to be selective as to the size of these fish. Therefore, brown bullhead from the degraded stream were larger than those from the reference stream, and size / age of fish can cause differences in the stress response (Table 3; Fatira et al., 2014). However, this size difference may not have been biologically significant as, based on other literature, even the larger individuals were still young and probably not sexually mature (Baumann et al., 1990; Scarola, 1987; Sinnott and Ringler, 1987). Therefore, the reduction in the stress response was likely caused by other factors, such as attenuation, where elevated GC concentrations interact with receptors to inhibit continued release (negative feedback) (Barton, 2002), or environmental pollutants that can interfere with steroidogenic cells that produce cortisol (Leblond et al., 2001) or inhibit its secretion, possibly through exhaustion of the HPA axis (Davies and Jackson, 2006; Hontela et al., 1992; Norris et al., 1999). An acute stress response liberates energy and prioritizes homeostasis to increase survival during short-term stressors. So regardless of the mechanism, a muted stress response may result in an inability to deal with environmental stressors (Barton, 2002; Romero, 2004). This could ultimately lead to decreased survival in these populations

Finally, logperch demonstrated an exaggerated (facilitated) response, which is sometimes seen when animals acclimate to a repeated stressor and then experience a novel stressor (Barton, Weiner, \& Schreck 1985; Schreck 2000). In these animals, it is likely that negative feedback signals are not strong enough to inhibit the combined stimulus of chronic and novel stressors 
(Dallman and Bhatnagar, 2001). The fact that logperch are a sensitive and specialist species probably enhances this facilitated response. Together, our results show that different species residing in identical habitats can respond to environmental stress in different ways, highlighting the variation in physiological ability to cope under poor environmental conditions, as well as the difficulty of predicting the glucocorticoid dynamics in wild animals (Dickens and Romero, 2013; Sih et al., 2011).

Interestingly, two of the five species examined did not demonstrate altered GC function despite residing in different quality habitats. More specifically, both pumpkinseed and white sucker showed no difference in either baseline or post-stress cortisol concentrations when compared across reference and degraded streams. There was no established time to maximal cortisol for all of the species examined, so it is possible that sample collection may not have occurred at the peak of cortisol concentrations. However, based on other related species (Acerete et al., 2004; Cook et al., 2012; Limsuwan et al., 1983; O'Connor et al., 2011), the timing of collections was likely near that of peak cortisol concentrations, and samples were collected in a way to ensure minimal impact on baseline cortisol concentrations (Romero and Reed 2005; Blevins et al. 2013). The lack of an effect of habitat quality was unexpected as previous studies have demonstrated variation in the physiological properties of resident organisms in response to reductions in habitat quality. For example, removal of terrestrial habitat was found to affect baseline and post-stress corticosterone concentrations in spotted salamanders Ambystoma maculatum (Homan et al., 2003). Similarly, Blevins et al. (2013) found that creek chub Semotilus atromaculatus collected from degraded watersheds (those dominated by agricultural land use) maintained physiological performance with a reduced stress response 
relative to creek chub collected from streams within forested watersheds (more pristine environments).

There are two hypotheses that could explain the lack of differences in the stress response for pumpkinseed and white sucker despite variation in habitat quality across the two sites examined. First, both species appear to be generalists (Leonard and Orth, 1986; Saint-Jacques et al., 2000; Tomecek et al., 2007) and previous work has shown that generalist species are less impacted by changes to environmental conditions than are specialists, likely because generalists have wider tolerance ranges, even though they may be less adapted to any single environment (Chevin et al., 2010; Minns et al., 1994). Pumpkinseed and white sucker may also possess a large capacity to display phenotypic plasticity relative to other species in this study. In fact, the plasticity of pumpkinseed has been acknowledged as facilitating their invasion of Europe (Tomecek et al., 2007). This would allow individuals residing in degraded environments to minimize the costly activation of the acute stress response. Not only can the capacity for plastic physiological changes vary across species (Chevin et al., 2010; Hendry et al., 2008), but variable environments are more likely to result in plastic changes than more stable environments (Baythavong, 2011; van Tienderen, 1997). Phenotypic plasticity can also occur based on the relative cost of inducing plastic changes to phenotype, competitive interactions, and evolutionary history (Hoffmann and Sgrò, 2011; Seebacher and Franklin, 2012; Sih et al., 2011; van Tienderen, 1997) It is therefore possible that habitat characteristics from the degraded environment (e.g., increased water temperature, more variable flow regime, more variable temperatures - see Blevins et al. 2013) resulted in plastic changes in the magnitude of the stress response in pumpkinseed and white sucker, thereby negating any inter-site differences in the stress response. Such plastic changes would be beneficial because they could eliminate any 
negative effects of chronic cortisol elevation, while still maintaining the ability to produce an acute stress response. Regardless of the mechanism, results from the current study clearly demonstrate that reduced stream quality did not influence the GC stress axis in some of the species examined.

Defining interspecific variation in the ability to respond to environmental challenges is critical for predicting 'winners' and 'losers' in the face of anthropogenic change (Angelier and Wingfield, 2013; Somero, 2010). Current research suggests that phenotypic plasticity is critically important for the persistence of species through human induced environmental change (Hendry et al., 2011, 2008; Hoffmann and Sgrò, 2011). Quantifying the capacity for animals to display plasticity in traits can be done with a number of different tests and experiments; however, studies of this nature often only examine a single species across an environmental or longitudinal gradient (Hoffmann and Sgrò, 2011). In the current study, we examined the response of multiple species when exposed to differing levels of anthropogenic disturbance and documented a variety of physiological responses. This result was likely due to species specific levels of plasticity that dictate their ability to cope behaviorally and physiologically with an altered environment. Our results suggest that pumpkinseed and white sucker possess a greater ability to cope with human disturbances and may fair better than other species in our study as they continue to spread. These types of studies can determine which species are most able to survive in changing environments and greatly increase our ability to predict the outcome of human disturbance (Angelier and Wingfield, 2013; Cooke et al., 2013).

The use of tissue cortisol extraction proved to be a valuable tool that increased the range of fish sizes available for a study such as this, and enabled us to examine GC function in a taxonomically diverse group of species, including three orders, four families, and five genera. 
The application of tissue cortisol extraction allows scientists to address multiple novel research questions regarding habitat characteristics and its effect on small species or early life stages. Utilizing this technique would greatly increase the habitats, life stages, and species able to be studied with physiological tools, thereby increasing their contribution to conservation ecology as a whole. While quantifying cortisol from tissue extracts has been used in laboratory studies (Sink et al., 2007), to our knowledge, the current study is the first to employ this methodology in the field.

By examining tissue cortisol in a stream community, our study revealed species-specific responses to the effects of stream quality on glucocorticoid function. We observed nearly the entire spectrum of responses, including no response, elevated baseline cortisol, a facilitated stress response, and an impaired stress response. While researchers have documented a variety of causes, we still cannot confidently predict the endocrine responses of chronically stressed wild animals (Dickens and Romero, 2013). Without understanding the conditions that result in the various changes to $\mathrm{GC}$ function, it is hard to determine how animals are affected by changes to stream quality and to relate the findings of physiological studies to managers (Cooke and O'Connor, 2010). From an ecological standpoint, any change in GC function - regardless of the direction - is potentially important (Dickens and Romero, 2013). Studies quantifying baseline and post-stress levels can, therefore, be used to determine if populations are chronically stressed, and by examining many populations within a community, we can determine species most able to cope with changing environments. Studies of GC function in communities have the ability to improve the basic understanding of the endocrine response to chronic stressors and the relationship between organism-, population-, and community-level processes. This type of study 
will increase the ability of researchers and managers to predict how ecosystems will be shaped by anthropogenic environmental change. 


\section{Acknowledgements}

These data were collected under funding from the U.S. Fish and Wildlife Service's Fish

Enhancement, Mitigation and Research Fund (Project \#2005-0129-023). This work was also supported by the USDA National Institute of Food and Agriculture, Hatch project ILLU-875947. We thank Jon Midwood, the staff of the Raisin Region Conservation Authority, and the Ontario Ministry of Natural Resources for enabling GIS data analysis. This work was also supported by the University of Illinois Graduate College, the College of Agricultural, Consumer and Environmental Sciences, and the Department Of Natural Resources and Environmental Sciences. S. J. Cooke was supported by the Discovery Grant program of the Natural Science and Engineering Research Council (NSERC) of Canada and the Canada Research Chairs program. J.M. Chapman was supported by an NSERC fellowship. 


\section{References}

Acerete, L., Balasch, J.C., Espinosa, E., Josa, A., Tort, L., 2004. Physiological responses in Eurasian perch (Perca fluviatilis, L.) subjected to stress by transport and handling. Aquaculture 237, 167-178.

Adams, S.M., Hill, W.R., Peterson, M.J., Ryon, M.G., Smith, J.G., A.J., S., 2002. Assessing recovery in a stream ecosystem: applying multiple chemical and biological endpoints. Ecol. Appl. 12, 1510-1527.

Adams, S.M., Shepard, K.L., Greeley, M.S., Jimenez, B.D., Ryon, M.G., Shugart, L.R., McCarthy, J.F., Hinton, D.E., 1989. The use of bioindicators for assessing the effects of pollutant stress on fish. Mar. Environ. Res. 28, 459-464.

Allan, J.D., 2004. Landscapes and Riverscapes: The Influence of Land Use on Stream Ecosystems. Annu. Rev. Ecol. Evol. Syst. 35, 257-284.

Angelier, F., Wingfield, J.C., 2013. Importance of the glucocorticoid stress response in a changing world: theory, hypotheses and perspectives. Gen. Comp. Endocrinol. 190, 118128.

Anscombe, F.J., Tukey, J.W., 1963. The Examination and Analysis of Residuals. Technometrics $5,141-160$.

Barcellos, L.J.G., Ritter, F., Kreutz, L.C., Quevedo, R.M., da Silva, L.B., Bedin, A.C., Finco, J., Cericato, L., 2007. Whole-body cortisol increases after direct and visual contact with a predator in zebrafish, Danio rerio. Aquaculture 272, 774-778.

Barton, B.A., 2002. Stress in Fishes : A Diversity of Responses with Particular Reference to Changes in Curculating Corticosteroids. Integr. Comp. Biol. 42, 517-525.

Barton, B.A., Weiner, G.S., Schreck, C.B., 1985. Effect of Prior Acid Exposure on Physiological Responses of Juvenile Rainbow Trout (Salmo gairdnera) to Acute Handling Stress. Can. J. Fish. Aquat. Sci. 4, 710-717.

Baumann, P.C., Harshbarger, J.C., Hartman, K.J., 1990. Relationship between liver tumors and age in brown bullhead populations from two Lake Erie tributaries. Sci. Total Environ. 94, 71-87.

Baythavong, B.S., 2011. Linking the spatial scale of environmental variation and the evolution of phenotypic plasticity: selection favors adaptive plasticity in fine-grained environments. Am. Nat. 178, 75-87.

Blevins, Z.W., Effert, E.L., Wahl, D.H., Suski, C.D., 2013. Land use drives the physiological properties of a stream fish. Ecol. Indic. 24, 224-235.

Chevin, L.-M., Lande, R., Mace, G.M., 2010. Adaptation, plasticity, and extinction in a changing environment: towards a predictive theory. PLoS Biol. 8, e1000357. 
Conover, D., Schultz, E.T., 1995. Phenotypic similarity and the evolutionary significance of countergradient variation. Trends Ecol. Evol. 10, 248-252.

Cook, K. V, O’Connor, C.M., McConnachie, S.H., Gilmour, K.M., Cooke, S.J., 2012. Condition dependent intra-individual repeatability of stress-induced cortisol in a freshwater fish. Comp. Biochem. Physiol. A. Mol. Integr. Physiol. 161, 337-43.

Cooke, S.J., O’Connor, C.M., 2010. Making conservation physiology relevant to policy makers and conservation practitioners. Conserv. Lett. 3, 159-166.

Cooke, S.J., Sack, L., Franklin, C.E., Farrell, A.P., Beardall, J., Wikelski, M., Chown, S.L., 2013. What is conservation physiology? Perspectives on an increasingly integrated and essential science. Conserv. Physiol. 1, 1-23.

Cooke, S.J., Suski, C.D., 2008. Ecological Restoration and Physiology: An Overdue Integration. Bioscience 58, 957-968.

Dallman, M.F., Bhatnagar, S., 2001. Chronic stress and energy balance: role of the hypothalamopituitary-adrenal axis, in: Handbook of Physiology; Section 7: The Endocrine System; Volume IV: Coping with the Environment: Neural and Endocrine Mechanisms. John Wiley \& Sons, Inc., pp. 197-210.

Davies, S.P., Jackson, S.K., 2006. The biological condition gradient: a descriptive model for interpreting change in aquatic ecosystems. Ecol. Appl. 16, 1251-1266.

Dickens, M.J., Romero, L.M., 2013. A consensus endocrine profile for chronically stressed wild animals does not exist. Gen. Comp. Endocrinol. 191, 177-89.

Dudgeon, D., Arthington, A.H., Gessner, M.O., Kawabata, Z.-I., Knowler, D.J., Lévêque, C., Naiman, R.J., Prieur-Richard, A.-H., Soto, D., Stiassny, M.L.J., Sullivan, C. a, 2006. Freshwater biodiversity: importance, threats, status and conservation challenges. Biol. Rev. Camb. Philos. Soc. 81, 163-82.

Environment, O.M. of the, 2009. Evaluation of Remedial Action Plan Tributary Nutrient Delisting Criteria for the St . Lawrence River, Cornwall, Area of Concern.

Fatira, E., Papandroulakis, N., Pavlidis, M., 2014. Diel changes in plasma cortisol and effects of size and stress duration on the cortisol response in European sea bass (Dicentrarchus labrax). Fish Physiol. Biochem. 40, 911-919.

Fahrig, L., 1997. Relative effects of habitat loss and fragmentation on population extinction. J. Wildl. Manage. 61, 603-610.

Falconer, D.S., 1990. Selection in different environments: effects on environmental sensitivity (reaction norm) and on mean performance. Genet. Res. 56, 57-70.

Filgueira, R., Chapman, J.M., Suski, C.D., Cooke, S.J., 2016. The influence of watershed land use cover on stream fish diversity and size-at-age of a generalist fish. Ecol. Indic. 60, $248-257$. 
Foley, J.A., Defries, R., Asner, G.P., Barford, C., Bonan, G., Carpenter, S.R., Chapin, F.S., Coe, M.T., Daily, G.C., Gibbs, H.K., Helkowski, J.H., Holloway, T., Howard, E. a, Kucharik, C.J., Monfreda, C., Patz, J. a, Prentice, C., Ramankutty, N., Snyder, P.K., 2005. Global consequences of land use. Science (80-. ). 309, 570-574.

Haddy, J.A., Pankhurst, N.W., 1999. Stress-induced changes in concentrations of plasma sex steroids in black bream. J. Fish Biol. 55, 1304-1316.

Hanson, K.C., Gravel, M. A., Graham, A., Shoji, A., Cooke, S.J., 2008. Sexual Variation in Fisheries Research and Management: When Does Sex Matter? Rev. Fish. Sci. 16, 421436.

Hendry, A.P., Farrugia, T.J., Kinnison, M.T., 2008. Human influences on rates of phenotypic change in wild animal populations. Mol. Ecol. 17, 20-9.

Hendry, A.P., Kinnison, M.T., Heino, M., Day, T., Smith, T.B., Fitt, G., Bergstrom, C.T., Oakeshott, J., Jørgensen, P.S., Zalucki, M.P., Gilchrist, G., Southerton, S., Sih, A., Strauss, S., Denison, R.F., Carroll, S.P., 2011. Evolutionary principles and their practical application. Evol. Appl. 4, 159-183.

Hoffmann, A.A., Sgrò, C.M., 2011. Climate change and evolutionary adaptation. Nature 470, 479-85.

Homan, R.N., Regosin, J. V., Rodrigues, D.M., Reed, J.M., Windmiller, B.S., Romero, L.M., 2003. Impacts of varying habitat quality on the physiological stress of spotted salamanders (Ambystoma maculatum). Anim. Conserv. 6, 11-18.

Hontela, A., Rasmussen, J.B., Audet, C., Chevalier, G., 1992. Impaired Cortisol Stress Response in Fish from Environments Polluted by PAHs, PCBs, and Mercury. Arch. Environ. Contam. Toxicol. 278-283.

Huey, R.B., 1991. Physiological Consequences of Habitat Selection. Am. Nat. 137, S91-S115.

Laub, B.G., Palmer, M.A., 2009. Restoration Ecology of Rivers, in: Likens, G.E. (Ed.), Encyclopedia of Inland Waters. Elsevier, pp. 332-341.

Leblond, V.S., Bisson, M., Hontela, A., 2001. Inhibition of cortisol secretion in dispersed head kidney cells of rainbow trout (Oncorhynchus mykiss) by endosulfan, an organochlorine pesticide. Gen. Comp. Endocrinol. 121, 48-56.

Leonard, P.M., Orth, D.J., 1986. Application and Testing of an Index of Biotic Integrity in Small, Coolwater Streams. Trans. Am. Fish. Soc. 115, 401-414.

Limsuwan, C., Limsuwan, T., Grizzle, J.M., Plumb, J.A., 1983. Stress Response and Blood Characteristics of Channel Catfish (Ictalurus punctatus) after Anesthesia with Etornidate. Can. J. Fish. Aquat. Sci. 40, 2105-2112. 
Magnuson, J.J., Crowder, L.B., Medvick, P. a., 1979. Temperature as an Ecological Resource. Integr. Comp. Biol. 19, 331-343.

Martínez-Mota, R., Valdespino, C., Sánchez-Ramos, M. a., Serio-Silva, J.C., 2007. Effects of forest fragmentation on the physiological stress response of black howler monkeys. Anim. Conserv. 10, 374-379.

Maule, A.G., Mesa, M.G., 1994. Efficacy of Electrofishing to Assess Plasma Cortisol Concentration in Juvenile Chinook Salmon Passing Hydroelectric Dams on the Columbia River. North Am. J. Fish. Manag. 14, 334-339.

Mesa, M.G., Schreck, C.B., 1989. Electrofishing Mark - Recapture and Depletion Methodologies Evoke Behavioral and Physiological Changes in Cutthroat Trout. Trans. Am. Fish. Soc. 118, 664-658.

Meybeck, M., 2004. The global change of continental aquatic systems: dominant impacts of human activities. Water Sci. Technol. 49, 73-83.

Milligan, C.L., 1996. Metabolic recovery from exhaustive exercise in rainbow trout. Comp. Biochem. Physiol. Part A Physiol. 113, 51-60.

Minns, C.K., Cairns, V.W., Randall, R.G., Moore, J.E., 1994. An Index of Biotic Integrity (IBI) for fish assemblages in the littoral zone of Great Lakes' Areas of Concern. Can. J. Fish. Aquat. Sci. 51, 1804-1822.

Miserendino, M.L., Casaux, R., Archangelsky, M., Di Prinzio, C.Y., Brand, C., Kutschker, A.M., 2011. Assessing land-use effects on water quality, in-stream habitat, riparian ecosystems and biodiversity in Patagonian northwest streams. Sci. Total Environ. 409, 612-24.

Miserendino, M.L., Masi, C.I., 2010. The effects of land use on environmental features and functional organization of macroinvertebrate communities in Patagonian low order streams. Ecol. Indic. 10, 311-319.

Mommsen, T.P., Vijayan, M.M., Moon, T.W., 1999. Cortisol in teleosts: dynamics, mechanisms of action, and metabolic regulation. Rev. Fish Biol. Fish. 9, 211-268.

Nagrodski, A., Suski, C.D., Cooke, S.J., 2012. Health, condition, and survival of creek chub (Semotilus atromaculatus) across a gradient of stream habitat quality following an experimental cortisol challenge. Hydrobiologia 702, 283-296.

Norris, D.O., Donahue, S., Dores, R.M., Lee, J.K., Maldonado, T. a, Ruth, T., Woodling, J.D., 1999. Impaired adrenocortical response to stress by brown trout, Salmo trutta, living in metal-contaminated waters of the Eagle River, Colorado. Gen. Comp. Endocrinol. 113, $1-8$.

O’Connor, C.M., Yick, C.Y., Gilmour, K.M., Van Der Kraak, G., Cooke, S.J., 2011. The glucocorticoid stress response is attenuated but unrelated to reproductive investment during parental care in a teleost fish. Gen. Comp. Endocrinol. 170, 215-21. 
Olden, J.D., Kennard, M.J., Leprieur, F., Tedesco, P. a., Winemiller, K.O., García-Berthou, E., 2010. Conservation biogeography of freshwater fishes: recent progress and future challenges. Divers. Distrib. 16, 496-513.

Poff, N.L., Allan, J.D., Bain, M.B., Karr, J.R., Prestegaard, K.L., Richter, B.D., Sparks, R.E., Stromberg, J.C., 1997. The Natural Flow Regime. Bioscience 47, 769-784.

Ramsay, J.M., Feist, G.W., Varga, Z.M., Westerfield, M., Kent, M.L., Schreck, C.B., 2006. Whole-body cortisol is an indicator of crowding stress in adult zebrafish, Danio rerio. Aquaculture 258, 565-574.

Ricciardi, A., Rasmussen, J.B., 1999. Extinction Rates of North American Freshwater Fauna. Conserv. Biol. 13, 1220-1222.

Richardson, C.J., 1994. Ecological functions and human values in wetlands: A framework for assessing forestry impacts. Wetlands 14, 1-9.

Romero, L.M., 2004. Physiological stress in ecology: lessons from biomedical research. Trends Ecol. Evol. 19, 249-55.

Romero, L.M., Butler, L.K., 2007. Endocrinology of Stress. Int. J. Comp. Psychol. 20, 89-95.

Romero, L.M., Reed, J.M., 2005. Collecting baseline corticosterone samples in the field: is under 3 min good enough? Comp. Biochem. Physiol. A. Mol. Integr. Physiol. 140, 73-9.

Ruxton, G.D., 2006. The unequal variance t-test is an underused alternative to Student's t-test and the Mann-Whitney U test. Behav. Ecol. 17, 688-690.

Saint-Jacques, N., Harvey, H.H., Jackson, D. a., 2000. Selective foraging in the white sucker (Catostomus commersoni). Can. J. Zool. 78, 1320-1331.

Scarola, J.F., 1987. Freshwater Fishes of New Hampshire. New Hampshire Fish and Game Department, Concord, NH, USA.

Schreck, C.B., 2000. Accumulation and Long-term Effects of Stress in Fish, in: Moberg, G.P., Mench, J.A. (Eds.), The Biology of Animal Stress. CAB International, pp. 147-158.

Seebacher, F., Franklin, C.E., 2012. Determining environmental causes of biological effects: the need for a mechanistic physiological dimension in conservation biology. Philos. Trans. R. Soc. Lond. B. Biol. Sci. 367, 1607-14.

Selye, H., 1973. The evolutioin of the stress concept. Am. Sci. 61, 692-699.

Sih, A., Ferrari, M.C.O., Harris, D.J., 2011. Evolution and behavioural responses to humaninduced rapid environmental change. Evol. Appl. 4, 367-387.

Sink, T.D., Kumaran, S., Lochmann, R.T., 2007. Development of a whole-body cortisol extraction procedure for determination of stress in golden shiners, Notemigonus crysoleucas. Fish Physiol. Biochem. 33, 189-193. 
Sink, T.D., Lochmann, R.T., Fecteau, K. a, 2008. Validation, use, and disadvantages of enzymelinked immunosorbent assay kits for detection of cortisol in channel catfish, largemouth bass, red pacu, and golden shiners. Fish Physiol. Biochem. 34, 95-101.

Sinnott, T.J., Ringler, N.H., 1987. Population Biology of the Brown Bullhead (Ictalurus nebulosus Lesueur). J. Freshw. Ecol. 4, 225-234.

Somero, G.N., 2010. The physiology of climate change: how potentials for acclimatization and genetic adaptation will determine "winners" and "losers". J. Exp. Biol. 213, 912-20.

Suski, C.D., Killen, S.S., Morrissey, M.B., Lund, S.G., Tufts, B.L., 2003. Physiological Changes in Largemouth Bass Caused by Live-Release Angling Tournaments in Southeastern Ontario. North Am. J. Fish. Manag. 23, 760-769.

Theodoropoulos, C., Iliopoulou-Georgudaki, J., 2010. Response of biota to land use changes and water quality degradation in two medium-sized river basins in southwestern Greece. Ecol. Indic. 10, 1231-1238.

Tomecek, J., Kovac, V., Katina, S., 2007. The biological flexibility of the pumpkinseed: a successful colonizer throughout Europe, in: Gherardi, F. (Ed.), Biological Invaders in Inland Waters: Profiles, Distribution, and Threats. Springer Netherlands, pp. 307-336.

Van Raaij, M.T., Pit, D.S., Balm, P.H., Steffens, a B., van den Thillart, G.E., 1996. Behavioral strategy and the physiological stress response in rainbow trout exposed to severe hypoxia. Horm. Behav. 30, 85-92.

Van Tienderen, P.H., 1997. Generalists, Specialists, and the Evolution of Phenotypic Plasticity in Sympatric Populations of Distinct Species. Evolution (N. Y). 51, 1372-1380.

Vitousek, P.M., Mooney, H.A., Lubchenco, J., Metillo, J.M., 1997. Human Domination of Earth's Ecosystems. Science (80-. ). 277, 494-499.

Wang, L., Lyons, J., Kanehl, P., Gatti, R., 2011. Influences of watershed land use on habitat quality and biotic integrity in wisconsin streams. Fisheries 22, 37-41.

Zimmerman, D.W., Zumbo, B.D., 1993. Rank Transformations and the Power of the Student t Test and Welch t' Test for Non-Normal Populations With Unequal Variances. Can. J. Exp. Psychol. 47, 523-539. 


\section{Figure Captions}

Figure 1: Baseline, post-stress, and responsiveness (baseline subtracted from post-stress) tissue cortisol values for the 5 species examined in our study. All samples were collected from a degraded stream and a reference stream in the vicinity of Cornwall, ON, CA in October of 2012. Sample sizes are indicated at the base of the bars. Significant differences between streams, within a category, are indicated by an asterisk (*) above the bars 
Table 1: Watershed land use characteristics (shown as percent of total watershed area) for the two streams used in this study. Watershed land use data were determined using Quantum GIS to integrate land use data from the Southern Ontario Land Resource Information System and a layer delineating watershed boundaries produced by the Raisin Region Conservation Authority

\begin{tabular}{ccc}
\hline Land use category & $\begin{array}{c}\text { Gunn Creek } \\
\text { (Degraded) }\end{array}$ & $\begin{array}{c}\text { Stream } \\
\text { Hoople Creek } \\
\text { (Reference) }\end{array}$ \\
\hline Forest & $5.0 \%$ & $13.9 \%$ \\
Wetland & $2.9 \%$ & $26.3 \%$ \\
Agriculture and other fields & $87.3 \%$ & $53.5 \%$ \\
Urban & $4.5 \%$ & $5.0 \%$ \\
Recreation & $0.0 \%$ & $0.6 \%$ \\
Resource extraction & $0.0 \%$ & $0.3 \%$ \\
\hline Total Watershed Area (ha) & 1038 & 9535 \\
\hline
\end{tabular}


Table 2: A brief description of the species used in this study and their basic characteristics. Habitat and life history characteristics were obtained from www.fishtraits.info (Frimpong and Angermeier, 2009) and feeding preferences were obtained from www.fishbase.org (Froese, 1990).

\begin{tabular}{|c|c|c|c|c|}
\hline Species & $\begin{array}{c}\text { Preferred in-stream } \\
\text { habitat }\end{array}$ & Preferred food & $\begin{array}{c}\text { Lifespan } \\
\text { (years) }\end{array}$ & $\begin{array}{c}\text { Age at } \\
\text { maturity } \\
\text { (years) }\end{array}$ \\
\hline Largemouth bass & $\begin{array}{l}\text { Vegetation, muck, silt, } \\
\text { clay, sand, gravel, or } \\
\text { cobble substrates }\end{array}$ & Fish, frogs, crayfish & 16 & 2.5 \\
\hline Pumpkinseed & $\begin{array}{l}\text { Can be found in } \\
\text { almost all habitats, } \\
\text { except large rocky } \\
\text { substrates }\end{array}$ & $\begin{array}{c}\text { Fish and other } \\
\text { vertebrates, fish eggs }\end{array}$ & 8 & 2 \\
\hline White sucker & $\begin{array}{l}\text { Can be found in } \\
\text { almost all habitats, } \\
\text { except large woody } \\
\text { debris }\end{array}$ & $\begin{array}{l}\text { Insects, diatoms, } \\
\text { crustaceans, } \\
\text { protozoa, algae }\end{array}$ & 8 & 3 \\
\hline Logperch & $\begin{array}{l}\text { Riffle; prefer gravel } \\
\text { and cobble substrate }\end{array}$ & $\begin{array}{l}\text { Larval and adult } \\
\text { insects, fish eggs }\end{array}$ & 4 & 1.5 \\
\hline Brown bullhead & $\begin{array}{l}\text { Vegetation, silt, clay, } \\
\text { sand, or gravel } \\
\text { substrates }\end{array}$ & $\begin{array}{c}\text { Algae, plants, } \\
\text { mollusks, crayfish, } \\
\text { worms, plankton, } \\
\text { insects, fish, fish } \\
\text { eggs }\end{array}$ & 11 & 2.5 \\
\hline
\end{tabular}


Table 3: Size ranges for the individuals used in this study. All samples were collected from a degraded stream and a reference stream in the vicinity of Cornwall, ON, CA in October of 2012. Length is presented as the mean, \pm standard error

\begin{tabular}{lcc}
\multicolumn{1}{c}{ Species } & Mean Length (mm) & Length Range (mm) \\
\hline Largemouth bass & $82 \pm 5$ & $57-127$ \\
$\begin{array}{l}\text { Degraded } \\
\text { Reference }\end{array} \quad 78 \pm 3$ & $63-117$ \\
$\quad$ Pumpkinseed & $69 \pm 4$ & $59-84$ \\
Degraded & $57 \pm 4$ & $44-111$ \\
Reference & & \\
$\quad$ White sucker & $128 \pm 14$ & $66-169$ \\
Degraded & $107 \pm 10$ & $73-240$ \\
Reference & & \\
$\quad$ Logperch & $72 \pm 2$ & $51-107$ \\
Degraded & $90 \pm 3$ & $69-111$ \\
Reference & & $122-207$ \\
Brown bullhead & $169 \pm 18$ & $63-154$ \\
Degraded & $82 \pm 4$ & \\
Reference & &
\end{tabular}


Table 4: Fulton's Condition Factor (K) for 4 of the 5 species used in this study. All samples were collected from a degraded stream and a reference stream in the vicinity of Cornwall, ON, CA in October of 2012. Condition is presented as mean, \pm standard error. Significant differences between streams are represented by an asterisk $(*)$. Sample size is given in parenthesis next to condition.

\begin{tabular}{lccc} 
& \multicolumn{2}{c}{ Condition $(\mathbf{K})$} & \\
Species & Reference & Degraded & P \\
\hline Largemouth bass & $1.13 \pm 0.03(14)$ & $1.27 \pm 0.03(16)$ & $\mathbf{0 . 0 0 3}^{*}$ \\
Pumpkinseed & $1.61 \pm 0.02(17)$ & $1.67 \pm 0.04(19)$ & 0.19 \\
White sucker & $0.93 \pm 0.03(14)$ & $0.91 \pm 0.05(4)$ & 0.63 \\
Logperch & $0.79 \pm 0.03(20)$ & $0.70 \pm 0.01(12)$ & 0.09
\end{tabular}


Figure

Figure 1
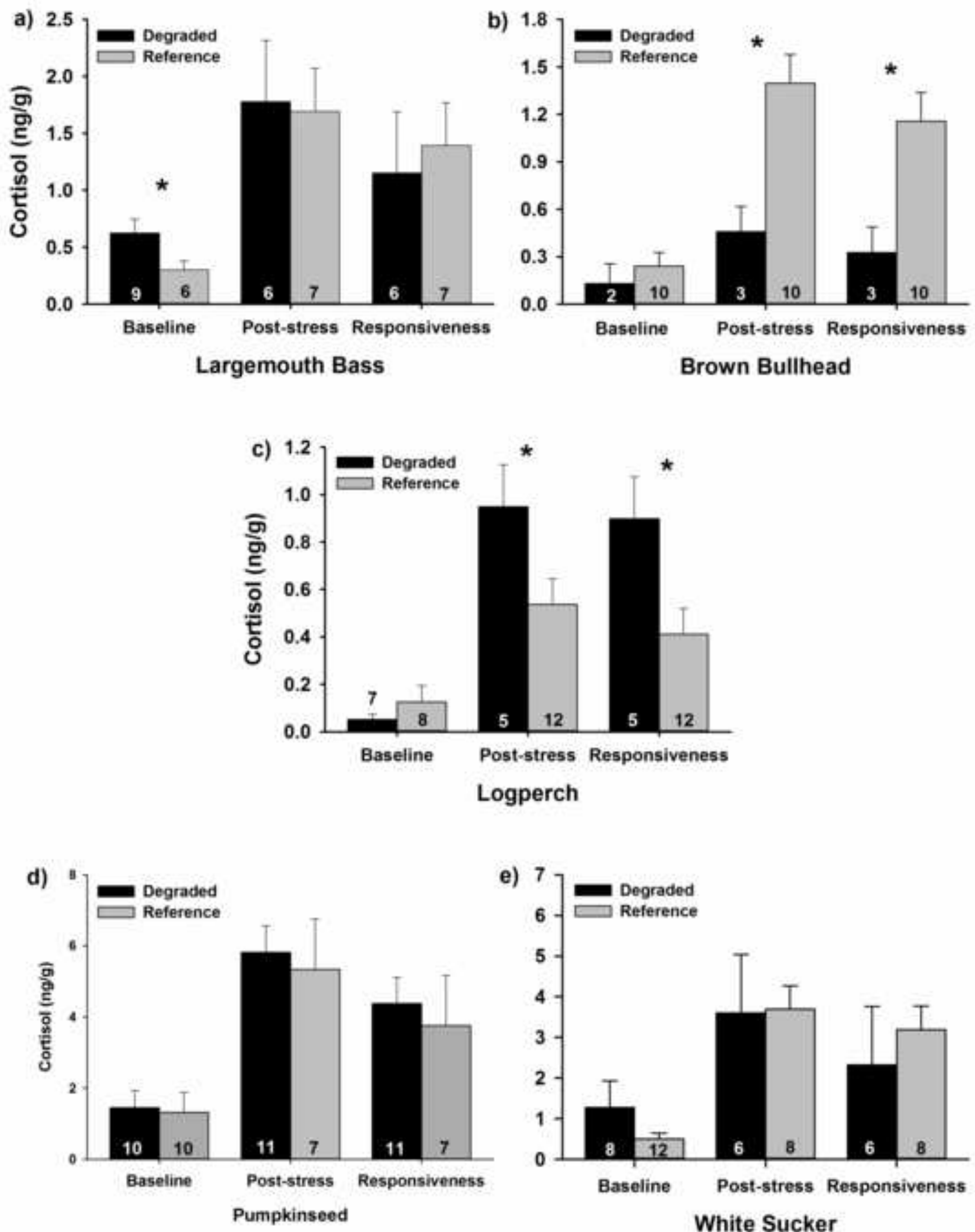

e)

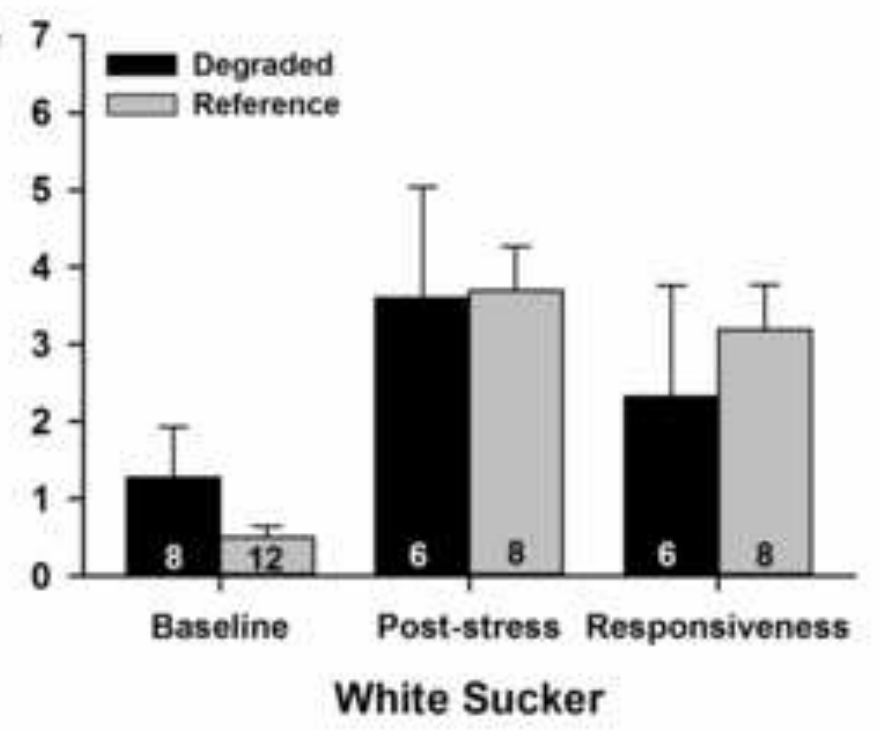

